\title{
STEREOTIP GENDER DI PERPUSTAKAAN
}

\author{
Mulyadi \\ Mahasiswa Program Doktor Ilmu Perpustakaan dan Informasi (IPII) Sunan Kalijaga dan Dosen Ilmu \\ Perpustakaan Fakultas Adab dan Humaniora UIN Raden Fatah Palembang \\ E-mail: mulyadi_uin@radenfatah.ac.id
}

\begin{abstract}
Abstrak
Konsep gender di perpustakaan merupakan konsep penting yang perlu dipahami dalam rangka membahas masalah kaum perempuan atau pustakawan perempuan yang ada di perpustakaan. Pemahaman ini sangatlah diperlukan dalam melakukan analisis untuk memahami persoalanpersoalan ketidakadilan sosial yang menimpa kaum perempuan di perpustakaan. Sehingga kita tidak lagi mengartikan gender sebagai seks (jenis kelamin) melainkan sebagai suatu sifat yang melekat pada kaum laki-laki dan perempuan yang dikonstruksikan secara sosial maupun kultural. Penyebab ketidak adilan terhadap pustakawan perempuan adalah pemahaman tentang Stereotip yaitu konsepsi mengenai sifat suatu golongan berdasarkan berasarkan prasangka yang subjektif dan tidak tepat atau dalam bahasa sehari hari dikenal dengan pelabelan. Teori feminis exixtentialist Simone De Beauvoir biasa menganalisis keberadaan pustakawan perempuan di perpustakaan. Pustakawan perempuan sebagai internalisasi liyan Stereotip, ternyata pustakawan perempuan tidak bebas memilih yang berikutnya dan jalannya dirinya sendiri. Sementara itu kita juga sepakat bahwa tidak semua pustakawan perempuan menjadi liyan, beberapa wanita memiliki Kesadaran dirinya dan pentingnya pekerjaannya sebagai pustakawan perempuan.
\end{abstract}

Keywords : Gender, stereotip, Library, Librarian.

\begin{abstract}
The gender concept in the library is an important concept that needs to be understood within the framework of discussing the issue of women or librarians in libraries. This understanding is needed in conducting an analysis to understand the problems of social injustice affecting women in libraries. We no longer interpret gender as sex (sex) as attributes to men and women who are socially and culturally constructed. The cause of injustice against female librarians is the notion of Stereotype that is the conception of the nature of a group based on subjective prejudices that are subjective and inappropriateness or in ordinary language known as labeling. Exixtentialist feminist theory Simone De Beauvoir used to analyze the guidance of female librarians in libraries. The female librarian as an internalization of the Stereotypes, it turns out that the female librarian is not free to choose the next and her own way. In the meantime we are not all librarian librarians, some women have Awareness of themselves and their duties as female librarians.
\end{abstract}

Keywords: Gender, stereotypes, Library, Librarian.

\section{PENDAHULUAN}

Pustakawan adalah seseorang yang memiliki kompetensi yang diperoleh melalui pendidikan dan/atau pelatihan kepustakawanan serta mempunyai tugas dan tanggung jawab untuk melaksanakan pengelolaan dan pelayanan perpustakaan (UU Nomor 43, 2007:3). Profesi pustakawan telah banyak diminati oleh sebagian masyarakat dan seringkali yang mengisi profesi pustakawan lebih banyak perempuan daripada laki-laki, karena berhubungan dengan masyarakat dan pelayanan. Pustakawan sebagai sumber daya manusia dalam 
perpustakaan dituntut untuk mampu menyediakan layanan untuk memenuhi kebutuhan masyarakat.

Berbicara mengenai pustakawan perempuan di perpustakaan maka terkait dengan istilah gender khususnya di perustakaan. Secara bahasa gender diartikan sebagai jenis kelamin (Hasan Shadily dkk., 1995:265). Kata gender dalam kamus bahasa Inggris di artikan : "Clasification of a noun or pronoun as masculine or feminine; sexual classification; sex; the male and female genders". Diartikan gender merupakan klasifikasi benda atau kata ganti benda sebagai maskulin ataum feminim, klasifikasi seksual, sek, gender laki-laki dan gender perempuan (A.S. Hornby, 1989:512). Namun istilah gender juga dibedakan dengan istilah jenis kelamin (seks). Gender adalah dimensi sosiokultural dan psikologis dari pria dan wanita, sedang seks berhubungan dengan dimensi biologis pria dan wanita. Gender masih diartikan oleh masyarakat sebagai perbedaan jenis kelamin. Masyarakat belum memahami bahwa gender adalah suatu konstruksi budaya tentang peran fungsi dan tanggung jawab sosial antara laki-laki dan perempuan di perpustakaan. Kondisi demikian mengakibatkan kesenjangan peran sosial dan tanggung jawab sehingga terjadi diskriminasi, terhadap laki-laki dan perempuan. Hanya saja bila dibandingkan, diskriminasi terhadap perempuan kurang menguntungkan dibandingkan laki-laki.

Penyebab ketidakadilan terhadap pustakawan perempuan karena masyarakat sudah memberikan kesimpulan bahwa perempuan memiliki pisik dan pemikiran yang lemah di banding dengan laki-laki atau dengan kata lain masyarakat sudah memberikan pelabelan yang kita kenal dengan stereotip. Stereotip merupakan pendapat mengenai suatu aspek kenyataan yang telah dibentuk sebelumnya, khususnya mengenai manusia dan kelompok-kelompok sosial berupa prasangka yang terlalu sederhana terhadap kelompok tertentu (Dali, 1982:282). Sehingga dapat disimpulkan bahwa stereotipe itu sendiri adalah pelabelan yang diawali dengan proses persepsi terhadap objek persepsi mengenai berbagai macam ciri dan sifat-sifat personal yang melekat (seakan permanen) pada sekelompok orang. Kita sering mempunyai stereotip (pelabelan) atau memberikan anggapan kepada orang Madura, Makasar, dan sebagian suku bangsa sebagai orang yang keras dan kasar perilakunya, sedang orang Jawa dan sebagian suku bangsa lain sebagai orang yang halus, lembut dan lain sebagainya. Barangkali saja perilaku yang sudah di-judment-kan kepada mereka tersebut merupakan hasil dari self fulfilling prophecies (peramalan diri) terhadap stereotipe yang sudah terbentuk sebelumnya. 
Penomena stereotip juga masuk ke perpustakaan karena terjadi perbedaan dalam banyak hal terkait dengan pustakawan laki-laki dan pustakawan perempuan. Sesungguhnya perbedaan gender dengan pemilahan sifat, peran, dan posisi tidak menjadi masalah sepanjang tidak melahirkan ketidakadilan. Namun pada kenyataannya perbedaan gender telah melahirkan berbagai ketidak adilan bagi kaum perempuan. Berbagai pembedaan peran, fungsi, tugas dan tanggung jawab serta kedudukan antara laki-laki dan perempuan di perpustakaan baik secara langsung maupun tidak langsung, dan dampak suatu peraturan perundang-undangan maupun kebijakan telah menimbulkan berbagai ketidakadilan karena telah berakar dalam adat, norma ataupun struktur masyarakat.

Ketidakadilan dan diskriminasi gender merupakan sistem dan struktur dimana baik perempuan maupun laki-laki menjadi korban dalam sistem tersebut. Berbagai pembedaan peran dan kedudukan antara perempuan dan laki-laki baik secara langsung yang berupa perlakuan maupun sikap, dan yang tidak langsung berupa dampak suatu peraturan perundangundangan maupun kebijakan telah menimbulkan berbagai ketidakadilan. Ketidakadilan gender terjadi karena adanya keyakinan dan pembenaran yang ditanamkan sepanjang peradaban manusia dalam berbagai bentuk yang bukan hanya menimpa perempuan saja tetapi juga dialami oleh laki-laki. Ketidakadilan gender merupakan bentuk perbedaan perlakuan berdasarkan alasan gender, seperti pembatasan peran, penyingkiran atau pilih kasih yang mengakibatkan terjadinya pelanggaran atas pengakuan hak asasinya, persamaan antara lakilaki dan perempuan, maupun hak dasar di perpustakaan. Ketidakadilan gender ini dapat bersifat : Langsung, yaitu pembedaan perlakuan secara terbuka dan berlangsung, baik disebabkan perilaku/sikap, norma/nilai, maupun aturan yang berlaku. Tidak langsung, seperti peraturan sama, tapi pelaksanaannya menguntungkan jenis kelamin tertentu. Sistemik, yaitu ketidakadilan yang berakar dalam sejarah, norma atau struktur masyarakat yang mewariskan keadaan yang bersifat membedabedakan.

Stereotif yang meyatakan bahwa perempuan adalah makhluk yang lemah berbanding terbalik dengan kenyataan bahwa tidak sedikit profil perempuan-perempuan yang kuat, rasional dan bahkan memiliki kapasitas kepemimpinan yang tinggi (Inayah, 2017:11). Inilah yang akan menjadi permasalahan dalam makalah ini bahwa mengapa di perpustakaan sering terjadi perlakuan yang tidak sama oleh penentu kebijakan terhadap pustakawan perempuan, baik di perpustakaan daerah maupun sekolah sampai perguruan tinggi. Mungkinkah penomena ini akan terus berlangsung ataukah di masa mendatang para pustakawan 
perempuan bisa menunjukan bahwa sudah sa'atnya antara pustakawan laki-laki dan perempuan berdiri sejajar dalam segala hal di dalam perpustakaan.

\section{PEMBAHASAN}

\section{Pengertian Stereotip dan Gender.}

Kata stereotip berasal dari gabungan dua kata Yunani, yaitu stereos yag berarti padatkaku dan typos yang bermakna model (Schneider, 2004:14). Stereotip adalah citra mental yang distandarisasi, pelabelan yang generalisasi yang dipegang oleh kelompok-kelompok sosial berdasarkan sikap prasangka atau kurangnya penilaian kritis (Inayah, 2017:24). Pelabelan yang di standarisasi biasanya merugikan, yang dilekatkan pada kelompok tertentu dalam hal ini perempuan sehingga perempuan mendapat citra negatif.

Stereotip memiliki tiga macam karakteristik: Pengkategorisasian atau pengelompokkan orang ke dalam ciri-ciri atau sifat-sifat tertentu yang bersifat relasional-perseptual, konsensus terhadap ciri atau sifat-sifat relasional-perseptual tersebut, dan adanya perbedaan atau ketidakcocokan antara ciri atau sifat-sifat relasional-perseptual dengan sifat atau ciri-ciri aktual. Oleh karena itu stereotipe juga diartikan sebuah rangkaian kepercayaan yang terstruktur mengenai berbagai macam ciri atau sifat-sifat personal dari sekelompok orang.

Stereotip tersebut adalah hasil generalisasi dari person per person, bukan perilaku kumulatif yang ada pada sebuah komunitas tertentu, namun karena pelabelan tersebut akhirnya masing-masing individu akan melakukan self fulfilling prophecies, melakukan pembenaran apa yang telah di sangkakan terhadap mereka, sehingga terlihat jelas ciri khas perilaku kumulatif tersebut pada tahap selanjutnya. Banyak efek yang diakibatkan oleh adanya stereotip. Akibat perilaku stereotip memunculkan apa yang disebut dengan marginalisasi. Marginalisasi adalah proses peminggiran yang merugikan salah satu pihak dan biasanya perempuan sebagai pihak yang interior dan tersubordir. Marginalisasi perempuan bisa bersumber atau terjadi pada wilayah Negara, keyakinan, masyarakat, agama (institusi dan tafsir agama), tempat kerja, keluarga atau diri sendiri (Fakih, 1996:14-15). Hasil studi yang dilakukan oleh beberapa psikolog Barat, dapat disimpulkan bahwa efek dari stereotipe antara lain adalah diskriminasi kelompok minoritas dan lemah. Sebagai contoh adalah adanya diskriminasi yang dilakukan oleh kelompok kulit putih yang mayoritas, terhadap kelompok kulit hitam yang minoritas di negara Barat. Diawali dengan stereotipe (pelabelan) negatif dari kelompok yang mayoritas terhadap kelompok yang minoritas, selanjutnya berpengaruh pada sikap mereka, dan akhirnya diimplementasikan secara nyata dalam perilaku agresif, dan menyerang terhadap kelompok lawannya tersebut. Apa yang terjadi setelah itu? Jawabnya 
tidak lain adalah perlawanan terhadap kelompok tertindas terhadap yang menindas, maka tak terelakan pula terjadinya peperangan.

Sedangkan konsep gender adalah suatu sifat yang melekat pada kaum laki-laki dan perempuan yang dikonstruksikan secara sosial maupun cultural. Misalnya, bahwa perempuan dikenal lemah lembut, cantik, emosional, atau keibuan. Sementara lakilaki dianggap kuat, rasional, jantan, perkasa. Ciri dan sifat itu sendiri merupakan sifat-sifat yang dapat dipertukarkan. Artinya ada laki-laki yang emosional, lemah lembut, keibuan, sementara juga ada perempuan yang kuat, rasional dan perkasa (Fakih, 1996:6-7). Dengan mengenali perbedaan gender sebagai sesuatu yang tidak tetap memudahkan kita untuk membangun gambaran tentang realitas relasi laki-laki dan perempuan yang dinamis, yang lebih tepat dan cocok dengan kenyataan yang ada dalam masyarakat. Hubungan gender adalah hubungan sosial antara laki-laki dan perempuan yang bersifat saling membantu atau sebaliknya, serta memiliki banyak perbedaan dan ketidaksetaraan. Hubungan gender berbeda dari waktu ke waktu dan antara masyarakat satu dengan masyarakat yang lain akibat perbedaan suku, agama, status sosial maupun nilai (tradisi dan norma yang dianut). Perbedaan konsep gender secara sosial telah melahirkan perbedaan peran perempuan dan laki-laki dalam masyarakatnya. Secara umum adanya gender telah melahirkan perbedaan peran, tanggung jawab, fungsi dan bahkan ruang tempat dimana manusia beraktivitas.

Sehingga dapat disimpulkan bahwa stereotipe gender adalah gambaran-gambaran yang ada dalam pikiran seseorang mengenai sifat khas dari karakteristik psikologis antara pria dan wanita secara sosial budaya. Atau bisa juga diartikan bahwa stereotip gender adalah proses menggeneralisasikan keseluruhan kelas dari suatu fenomena berdasarkan sedikit pengetahuan yang di dapat dari anggota kelas tersebut. Jika kita bisa menghilangkan stereotip gender di perpustakaan maka akan muncul kesetaraan gender berarti kesamaan kondisi bagi laki-laki dan perempuan untuk memperoleh kesempatan serta hak-haknya sebagai manusia, agar mampu berperan dan berpartisipasi dalam kegiatan politik, hukum, ekonomi, sosial budaya, pendidikan dan pertahanan keamanan nasional (Hamkamnas), serta kesamaan dalam menikmati hasil pembangunan tersebut. Kesetaraan gender juga meliputi penghapusan diskriminasi dan ketidakadilan struktural baik terhadap laki-laki maupun perempuan

\section{Stereotip Peran Gender di perpustakaan}

Setelah mengetahui tentang stereotipe secara umum, maka tidak lepas pula peran gender sering dijadikan sebagai salah satu pokok dalam pembahasan stereotip gender yang merupakan ekspektasi sosial yang merumuskan bagaimana pria dan wanita seharusnya 
berpikir, merasa, dan berbuat, adalah produk dari stereotipe. Stereotip secara kultural menentukan gambaran yang mendistorsi bagian kognitif individu dan persepinya tentang dunia atas realitas (Sunarto, 2009:237). Oleh karenanya apa yang hendak ditampilkan atau dibangun oleh media mengenai stereotip tertentu memiliki pengaruh yang besar dalam masyarakat. Masyarakat akan cenderung menganggap benar apa yang dikonstruksi oleh media.

Seperti yang telah di jelaskan bahwa stereotipe merupakan pelabelan yang diawali dengan proses persepsi terhadap objek persepsi mengenai berbagai macam ciri dan sifat-sifat personal yang melekat (seakan permanen) pada sekelompok orang. Maka peran gender merupakan hasil pelabelan yang akhirnya menjadi ekspektasi (harapan) sosial, dan sangat sulit untuk diadakan perubahan konsep karena sudah menjadi stereotipe. Gender sendiri merupakan pelabelan atas laki-laki dan perempuan. Kontruksi ini tidak lagi membedakan laki-laki dan perempuan atas perbedaan seks yang dimiliki. Dasar sosialisasi ini secara kuat telah membentuk ideologi gender, melalui kontruksi sosial yang melembaga. Misalnya, perempuan dikenal lemah lembut, cantik, emosional dan keibuan. Sementara laki-laki dianggap kuat, rasional, perkasa, dan jantan.

Stereotip adalah bentuk ketidakadilan. Secara umum stereotip merupakan pelabelan atau penandaan terhadap suatu kelompok tertentu, dan biasanya pelabelan selalu berakibat pada ketidakadian, sehingga dinamakan stereotip negatif. Hal ini disebabkan pelabelan yang sudah melekat pada laki-laki, misalnya laki-laki adalah manusia yang kuat, rasional, jantan, perkasa. Sedangkan perempuan adalah makhluk yang lembut cantik, emosional atau keibuan (Trisakti dkk., 2009:16-17). Streotip gender adalah kategori luas yang merefleksikan kesan dan keyakinan tentang perilaku laki-laki dan perempuan. Semua streotip baik berhubungan dengan gender, etnis atau kategori lain mengacu pada citra anggota tersebut. Banyak streotip yang muncul dan bersifat umum sehingga menjadi ambigu, misalkan kategori maskulin dan feminin.

Stereotip gender mencegah perempuan mendapatkan pekerjaan-pekerjaan tertentu, mencegah promosi tertentuk untuk perempuan serta menghambat perempuan mendapatkan upah yang sama dalam pekerjaannya. Adanya streotip tersebut tentu saja akan muncul banyak streotip yang dikontruksi oleh masyarakat sebagai hasil hbungan sosial tentang perbedaan laki-laki dan perempuan. Oleh karena itu perempuan identik dengan pekerjaanpekerjaan dirumah, maka peluang perempuan untuk bekerja di luar rumah sangat terbatas, bahkan ada perempuan yang berpendidikan tinggi tidak pernah menerapkan pendidikannya 
untuk mengaktualisasikan diri. Akibat adanya streotip (pelabelan) banyak tindakan-tindakan yang seolah-olah sudah merupakan kodrat.

Simone de Beaviour adalah tokoh dari feminis eksistensialisme. Beauvoir menganalisis situasi perempuan pada begitu banyak ranah (sastra, agama, politik, kerja, pendidikan) yang berbeda dan tidak memiliki sumber historis yang sebanding. Beauvoir memberikan sumbangsih pemikiran feminis tentang keliyanan perempuan (Rosemarie, 2004:253-254). liyan adalah perempuan yang tidak dapat menggariskan hidupnya sendiri, tidak bebas memilih sesuai dengan keinginannya ,cenderung diarahkan dan terstreotip oleh keluarga maupun lingkungan untuk bekerja di perpustakaan sebagai pustakawan atau staf perpustakaan. Transendensi keliyanan menjadi diri dilakukan bukan dengan cara yang mudah tetapi penuh perjuangan. Perempuan sebagai diri terus menemukan arti hidupnya dengan cara melakukan perjuangan untuk mencari jatidiri menemukan makna dalam profesinya. Setelah menemukan arti dirinya dan kesadaran makna dirinya ia akan secara tulus menjalankan peranan profesinya.

Perempuan dikontruksikan sebagai makhluk yang perlu dilindungi, kurang mandiri, tidak rasional, hanya mengandalkan perasaan, dan lain-lain. Konsekuensinya, muncul batasan-batasan yang menempatkan perempuan pada ruang penuh dengan aturan baku yang perlu dijalankan. Padahal, banyak sisi positif dari perempuan yang membedakannya dengan laki-laki dan jarang diekspos. Yaitu watak dan karakter. Seperti kemampuan pengendalian diri, kekuatan emosi, kepekaan sosial. Konsep pembakuan peran gender yang mengotakkotakkan peran laki-laki atau suami dan perempuan atau istri ini hanya memungkinkan perempuan berperan di wilayah domestik yakni sebagai pengurus rumah tangga sementara laki-laki di wilayah publik sebagai kepala keluarga dan pencari nafkah utama.

Kata kunci untuk memahami gender ada pada kata pembagian, yang dapat dibedakan pada dua sifat, yaitu : Pembagian yang sifatnya kodrati dan pembagian yang bersifatnya berubah-rubah sehingga dapat dipertukarkan. Pembagian yang pertama merupakan pemberian Tuhan yang tidak dapat dipertukarkan antara laki-laki dan perempuan dinamakan sebagai pembagian seksual. Sedangkan pembagian peran, sifat dan watak serta tanggungjawab yang dapat dipertukarkan antara laki-laki dan perempuan itulah yang dinamakan gender. Dari pembagian itulah kemudian muncul perbedaan gender. Oleh karena itu, gender sesungguhnya berkaitan erat dengan proses keyakinan bagaimana seharusnya lakilaki dan perempuan diharapkan untuk berfikir dan bertindak sesuai dengan ketentuan sosial dan budaya dimana mereka berada. Menurut Simone De Beauvoir kebebasan yang diberikan 
kepada perempuan haruslah kebebasan yang sama diberikan kepada laki-laki. Kebebasan yang sejati adalah kebebasan yang didasarkan pada kesadaran dalam diri sendiri (Riyanto, 2011:110). Berdasarkan keyakinan itulah masyarakat membedakan peran dan fungsi gender sesuai dengan kebutuhannya. Demikian bahwa stereotip peran gender juga merupakan kategori luas yang merefleksikan kesan dan keyakinan tentang apa perilaku yang tepat untuk pria dan wanita.

\section{Ideologi Stereotif Gender, Partriarki dan Agama di Perpustakaan}

Adanya stereotip yang telah melekat pada pustakawan perempuan melahirkan patriarki. Pelabelan, ciri, sifat perempuan dan laki-laki akan melahirkan perbedaan dalam segala hal di perpustakaan. dibedabedakan tersebut diatas, dipengaruhi beberapa faktor. Sebagian memandang karena faktor biologis, dan sebagian yang lain menekankan pada faktor sosial atau kognitif. Dalam konteks keagamaan, karena yang dikembangkan oleh kaum laki-laki, maka dalam prakteknya pemahaman agama memberik keistimewaan terhadap kaum laki-laki dan pengalamannya dibanding kaum perempuan di perpustakaan.

Memang para di ahli tafsir bersepakat bahwa kodrat perempuan di hadapan Allah sama dengan laki-laki yang membedakannya adalah kadar ketaqwaannya. Dasar normative tentang kesetaraan ini biasanya merujuk pada Q.S. Al-Hujarat : 13 yang berbunyi :

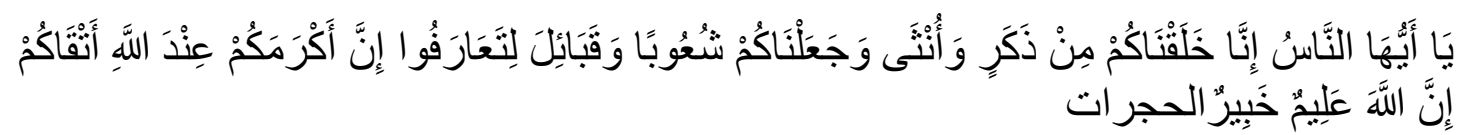

Artinya : "Hai manusia, Sesungguhnya Kami menciptakan kamu dari seorang laki-laki dan seorang perempuan dan menjadikan kamu berbangsa - bangsa dan bersuku-suku supaya kamu saling kenal-mengenal. Sesungguhnya orang yang paling mulia diantara kamu disisi Allah ialah orang yang paling taqwa diantara kamu. Sesungguhnya Allah Maha mengetahui lagi Maha Mengenal."

Tetapi dalam prakteknya tetap saja mengutamakan kaum laki-laki. Sebagaimana yang dicontohkan dalam ayat Al-Qur'an lainnya :

1. Tentang laki-laki setingkat lebih tinggi di surat Al-Baqarah : 228

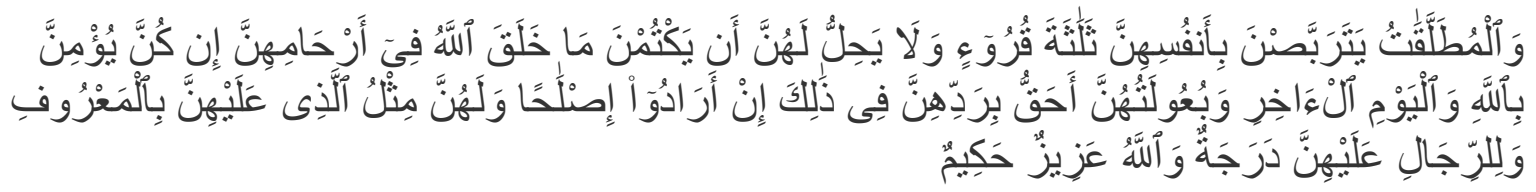

Artinya : "Wanita-wanita yang ditalak hendaklah menahan diri (menunggu) tiga kali quru Tidak boleh mereka mehnyembunyikan apa yang diciptakan Allah dalam rahimnya, jika mereka beriman kepada Allah dan hari akhirat. Dan suamisuaminya berhak merujukinya dalam masa menanti itu, jika mereka (para suami) itu menghendaki ishlah. Dan para wanita mempunyai hak yang 
seimbang dengan kewajibannya menurut cara yang ma'ruf. Akan tetapi para suami mempunyai satu tingkatan kelebihan daripada isterinya. Dan Allah Maha Perkasa lagi Maha Bijaksana”. (Al-Baqarah : 228)

2. Laki-laki pelindung perempuan di suran An-Nisa : 34

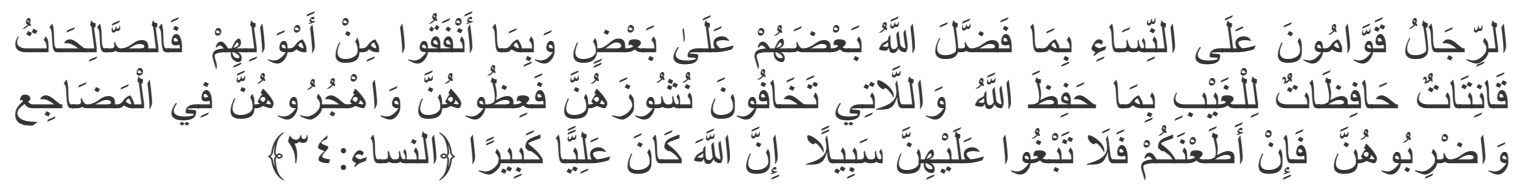

Artinya : "Kaum laki-laki itu adalah pemimpin bagi kaum wanita, oleh karena Allah telah melebihkan sebahagian mereka (laki-laki) atas sebahagian yang lain (wanita), dan karena mereka (laki-laki) telah menafkahkan sebagian dari harta_mereka. Sebab itu maka wanita yang saleh, ialah yang taat kepada Allah lagi memelihara diri ketika suaminya tidak ada, oleh karena Allah telah memelihara (mereka). Wanita-wanita yang kamu khawatirkan nusyuznya, maka nasehatilah mereka dan pisahkanlah mereka di tempat tidur mereka, dan pukullah mereka. Kemudian jika mereka mentaatimu, maka janganlah kamu mencari-cari jalan untuk menyusahkannya. Sesungguhnya Allah Maha Tinggi lagi Maha Besar." ( QS. An-Nisa : 34

3. Laki-laki mendapat warisan lebih banyak di surat An- Nisa ayat : 11.

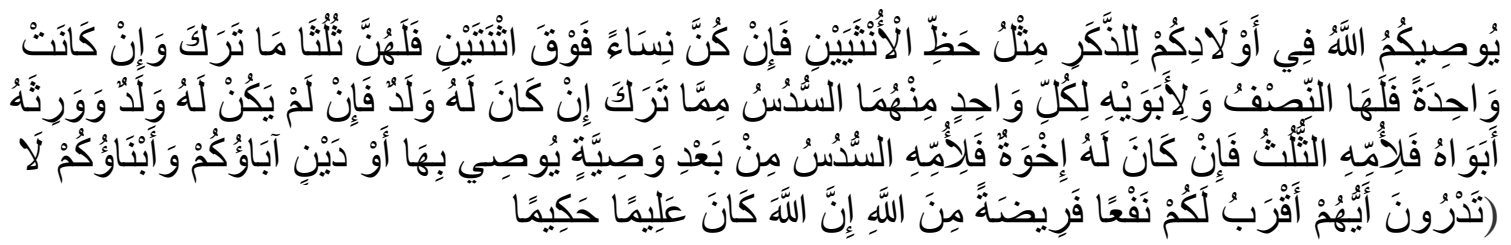

Artinya: “Allah mensyari'atkan bagimu tentang (pembagian pusaka untuk) anak-anakmu. Yaitu : bahagian seorang anak lelaki sama dengan bagahian dua orang anak perempuan]; dan jika anak itu semuanya perempuan lebih dari dua, maka bagi mereka dua pertiga dari harta yang ditinggalkan; jika anak perempuan itu seorang saja, maka ia memperoleh separo harta. Dan untuk dua orang ibubapa, bagi masing-masingnya seperenam dari harta yang ditinggalkan, jika yang meninggal itu mempunyai anak; jika orang yang meninggal tidak mempunyai anak dan ia diwarisi oleh ibu-bapanya (saja), maka ibunya mendapat sepertiga; jika yang meninggal itu mempunyai beberapa saudara, maka ibunya mendapat seperenam. (Pembagian-pembagian tersebut di atas) sesudah dipenuhi wasiat yang ia buat atau (dan) sesudah dibayar hutangnya. (Tentang) orang tuamu dan anak-anakmu, kamu tidak mengetahui siapa di antara mereka yang lebih dekat (banyak) manfaatnya bagimu. Ini adalah ketetapan dari Allah. Sesungguhnya Allah Maha Mengetahui lagi Maha Bijaksana." (QS. An-Nisa:11).

Berbagai dasar dari sudut pandang agama inilah pada akhirnya masih saja akibat dari stereotip melahirkan patriarki di perpustakaan. Perempuan merupakan sebuah konsep derifatif yang keberadaanya hanyalah sebagai objek perhatian laki-laki. Perempuan secara historis dan diskursif dibentuk dan selalu bersifat relative terhadap berbagai kategori yang 
berubah, perempuan adalah sebuah kolektifitas yang mudah berubah dimana para perempuan dapat diposisikan secara sangat berbeda (Castelli, 2001:5). Hal ini juga terjadi pada pustakawan perempuan yang ada di perpustakaan.

Pustakawan perempuan pada saat ini digambarkan sebagai manusia yang harus hidup dalam situasi dilematis. Di satu sisi pustakawan perempuan dituntut untukberperan dalam semua sektor, tetapi di sisi lain muncul pula tuntutan lain agar pustakawan perempuan tidak melupakan kodrat mereka sebagai perempuan. Contohnya situasi tersebut dialami oleh pustakawan perempuan di perpustakaan yang berkarir. Di satu sisi perempuan karir merasa terpanggil untuk mendarmabaktikan bakat dan keahliannya bagi perkembangan perpustakaan, namun di sisi lain mereka dihantui oleh opini yang ada dalam perpustakaan yang melihat bahwa pustakawan perempuan sebagai salah satu sumber ketidakberhasilan apabila menduduki jabatan di perpustakaan.

Sementara di perpustakaan yang tenaga pengelola diisi oleh pustakawan perempuan dan laki-laki yang semuanya juga memiliki peranan dan kedudukan yang sama. Peranan adalah konsep yang digunakan untuk mengetahui pola tingkah laku yang teratur dan relatif bebas dari orang-orang tertentu yang kebetulan menduduki berbagai posisi dan menunjukkan tingkah laku yang sesuai dengan tuntutan peranan yang dilakukannya (Blalock, 1987:19). Berbicara mengenai peran perempuan dan laki-laki dalam masyarakat, maka tidak akan terlepas dari sebuah dikotomi culture dan nature. Dimana hal tersebut menunjukkan stratifikasi jenis kelamin tersebut melahirkan suatu ideology yang memisahkan sektor kehidupan ke dalam dua domain, yaitu domestik dan publik. Ideologi tersebut menempatkan perempuan pada sektor domestik dan laki-laki pada sektor public (Abdullah, 2001:106). Ideologi tersebut dikiatkan oleh pranata dan lembaga sosial dalam masyarakat. Hal ini pada akhirnya menjadi realitas sosial mengenai status dan peran yang harusdimainkan oleh perempuan dan laki-laki.

Seorang pemimpin memegang peranan penting dalam sebuah struktur kepemimpinan. Seorang pemimpin harus memenuhi persyaratan visi, semangat, karakter, integritas, kapabilitas, energi, relasi, respon, otoritas, dan respek yang baik (Tikno, 2003:5-12). Tidak mengherankan jika persyaratan atau ciri untuk menjadi seorang pemimpin akhirnya mendominasi pandangan bahwa sosok yang lebih tepat untuk menjadi pemimpin adalah lakilaki bukan perempuan. Pada era sekarang ini sudah mengalami pergeseran pandangan, bahwa pemimpin masa depan yaitu dibutuhkan pemimpin berkualitas dengan paradigma baru. Pemimpin masa depan bukan lagi pemimpin diangkat atas dasar kekuasaan, manipulasi, 
pemaksaan kedudukan, asal usul maupun gender (Martha, 2002:16). Masyarakat masa depan adalah masyarakat demokratis, didasari penghormatan dan pengakuan hak asasi manusia. Terbukanya kesempatan bagi perempuan untuk berperan sebagai pemimpin, berarti membuka juga peluang untuk perempuan dalam mengambil bagian dalam penentuan keputusan dan kebijakan (Murniati, 2004:55). Begitu juga di perpustakaan selama ini, setiap kepala perpustakaan sebagai pimpinan tertinggi hampir selalu dikaitkan dengan sifat laki-laki yang maskulin sehingga hampir semua keputusan didominasi oleh kaum pria. Perempuan sebenarnya juga mempunyai peran dalam pengambil keputusan, tetapi menduduki posisi subordinat saja. Jadi, ketika kepala perpustakaan dipegang oleh seorang pustakawan perempuan, maka kesempatan yang sama juga diberikan kepada perempuan untuk menentukan keputusan demi terwujudnya tujuan organisasi, sehingga persamaan peran dan fungsi kesetaraan gender dalam masyarakat dapat diaplikasikan secara baik.

\section{PENUTUP}

\section{Simpulan}

Diskriminasi gender telah melahirkan ketimpangan dalam kehidupan berkeluarga, bermasyarakat, berbangsa dan bernegara, termasuk di perpustakaan. selain itu ketimpangan lebih banyak dialami perempuan dari pada laki-laki. Perempuan dan laki-laki ketika memasuki dunia pekerjaan membawa stereotip tersendiri kedalamnya. Perempuan mengalami stereotip yang melekat pada diri perempuan ketika akan memasuki ranah publik, tidak hanya disitu ketika mereka telah berada di ranah publik ada stereotip yang juga melekat dan membuat mereka mengalami diskriminasi dalam bentuk pemisahan bidang kerja.

Bahkan dari segi pemahaman agama pun masih saja tidak ada keberpihakan terhadap kaum perempuan. Secara keseluruhan derajat manusia ditentukan oleh kadar taqwanya, tetapi dalam prakteknya banyak-ayat-ayat yang mengutamakan kaum laki-laki, seperti dalah hal kedudukan, waris, pelindung dll.

Di perpustakaan memang terdapat pembagian kerja berdasarkan jenis kelamin. Perempuan cenderung mengisi pekerjaan pelayanan dan laki-laki ditempatkan pada pekerjaan lapangan dan berhubungan dengan fisik yang kuat dan kecanggihan teknologi. Bagi perempuan yang ingin berprofesi pustakawan. Jangan sampai memutuskan berprofesi sebagai pustakawan karena paksaan terlebih karena terstreotip bahwa perpustakaan sesuai dengan karakter perempuan. Sebenarnya banyak pekerjaan yang bisa dikerjakan oleh perempuan tanpa melihat gender. Ketika perempuan memutuskan untuk bekerja sebagai pustakawan 
harus berdasarkan kesadaran dirinya sendiri. Sehingga kualitaslah yang akan membuktikan jika menjadi pustakawan karena kesadaran.

Pimpinan tertinggi di perpustakaan adalah di perpustakaan, selama ini di dominasi oleh pustakawan laki-laki di masa yang akan datang siapapun bisa menduduki kepemimpinan tersebut. Dan sedikit demi sedikit stereotif yang melahirkan patriarki di perpustakaan berkurang, sesuai dengan kemampuan dan integritas tanpa melihat apakah dia laki-laki atau perempuan, semuanya memiliki kedudukan dan hak yang sama.

\section{DAFTAR PUSTAKA}

Abdullah, Irwan. Sangkan Paran Gender. Yogyakarta: Pustaka Pelajar, 2001.

Blalock, Hubert M. Jr. Pengantar Penelitian Sosial. Jakarta: Rajawali Press, 1987.

Castelli, Elizabet A. Women, Gender, Religion. New York: Palgrave, 2001.

Dali, Gulo. Kamus Psycology. Bandung: Tonis, 1982.

Echols, Jhons M, and Hasan Shadily. Kamus Inggris-Indonesia. Jakarta: Gramedia, 1995.

Fakih, Mansour. Analisis Gender \& Transformasi Sosial (Gender Analysis \& Social Transformation. Yogyakarta: Pustaka Pelajar, 1996.

Fakih Mansour. Membincang Feminisme Biskursus Gender Perspektif Islam. Surabaya: Risalah Gusti, 1996.

Hornby, A.S. Oxford Advanced Learnr's Dictionary. Oxford: Oxford Univerity Press, 1989.

Inayah, Rohmaniyah. Gender Dan Kontruksi Patriarki Dalam Tafsir Agama. Yogyakarta: Diandra Pustaka Indonesia, 2017.

Martha, Tilaar. Leadership Quotient: Perempuan Pemimpin Indonesia. Jakarta: Grasindo, 2002.

Murniati, A. Nunuk P. Getar Gender: Buku Kedua, Perempuan Indonesia Dalam Perspektif Agama, Budaya Dan Keluarga. Magelang: Indonesiatera, 2004.

RI, Perpustakaan Nasional. UU No.43 Tahun 2007 Tentang Perpustakaan. Jakarta: PNRI, 2007.

Riyanto, Armada. Aku \& Liyan. Malang: Widya Sasana Publication, 2011.

Rosemarie, Putnam Tong. Feminis Thought, Terjemahan Aquarini. Yogyakarta: Jalasutra, 2004.

Schneider, David J. The Psychology Of Stereotyping. New York: The Guilford Press, 2004. 
Sugiartati, Handayani, Trisakti. Konsep Dan Teknik Penelitian Gender. Malang: Universitas Negeri Malang, 2005.

Sunarto. Televisi, Kekerasan, Dan Perempuan. Jakarta: PT. Kompas Media Nusantara, 2009.

Tikno, Lensufie. Leadership Untuk Profesional Dan Mahasiswa. Jakarta: Erlangga, 2003. 